\title{
Effect of High-Temperature Events When Heading into the Maturity Period on Summer Maize (Zea mays L.) Yield in the Huang-Huai-Hai Region, China
}

\author{
Shengbao Wei, Jing Liu, Tiantian Li, Xiaoying Wang, Anchun Peng and Changqing Chen * \\ Institute of Applied Ecology, Nanjing Agricultural University, Nanjing 210095, China; \\ 2019101014@njau.edu.cn (S.W.); 2018101004@njau.edu.cn (J.L.); 2019801188@njau.edu.cn (T.L.); \\ 2018101027@njau.edu.cn (X.W.); 2020101021@njau.edu.cn (A.P.) \\ * Correspondence: cn828@njau.edu.cn
}

Received: 29 October 2020; Accepted: 27 November 2020; Published: 29 November 2020

\begin{abstract}
The predicted increase in the frequency of extreme climatic events in the future may have a negative effect on cereal production, but our understanding of the historical trends of high-temperature events associated with climate change and their long-term impact on summer maize yield is limited. Based on an analysis of historical climate and summer maize yield data from 1980 to 2016 in the Huang-Huai-Hai (3H) region of China, we calculated two high-temperature event indices, namely, high-temperature hours (HTH) and high-temperature degrees (HTD, the sum of the differences between $35^{\circ} \mathrm{C}$ and above), and then investigated the temporal trend of high-temperature events from maize heading to maturity and their impact on the yield of summer maize. Our results indicated that the air temperature showed a significant upward trend when heading into the maturity period of summer maize in the 3H region from 1980-2016 and that the increase was greater in the northern Huang-Huai-Hai $(\mathrm{N} 3 \mathrm{H})$ region than in the southern Huang-Huai-Hai $(\mathrm{S} 3 \mathrm{H})$ region. The intensity of high-temperature events when heading into the maturity period increased considerably from 1980 to 2016 in the $3 \mathrm{H}$ region, especially in the $\mathrm{S} 3 \mathrm{H}$ region. The HTH and HTD increased by $1.30 \mathrm{~h}$ and $0.80{ }^{\circ} \mathrm{C}$ per decade in the $\mathrm{S} 3 \mathrm{H}$ region, respectively. Moreover, a sensitivity analysis of panel data showed that the increases in HTH and HTD when heading into the maturity period had a consistent negative effect on yield in $\mathrm{S} 3 \mathrm{H}$ and $\mathrm{N} 3 \mathrm{H}$ regions; this effect was more obvious in the $\mathrm{S} 3 \mathrm{H}$ region. In the $\mathrm{S} 3 \mathrm{H}$ region, a $1 \mathrm{~h}$ increase in $\mathrm{HTH}$ was found to be associated with a $0.45-1.13 \%$ decrease in yield and a $1{ }^{\circ} \mathrm{C}$ increase in HTD could result in a yield loss of $1.34-4.29 \%$. High-temperature events were detrimental to summer maize production, and the severity of this effect was projected to increase in the $3 \mathrm{H}$ region. In this study, we used two indices (HTH and HTD) to quantify the impact of high-temperature events on summer maize yield during the critical growth phase (heading to maturity) at a small timescale (hours and days). The results of this study can provide a reference for policymakers to use in the formulation of corresponding climate change adaptation strategies.
\end{abstract}

Keywords: climate change; high-temperature events; summer maize; heading; maturity; yield

\section{Introduction}

With global climate warming, the frequency and severity of extreme weather events have increased [1,2], which have had a negative impact on the growth and development of crops [3,4]. High temperatures that exceed critical thresholds for plants are usually referred to as heat stress, and crops are more sensitive to high temperatures during their reproductive stages than during their vegetative stages [5]. During this critical growth period, even short-term high-temperature stress can cause drastic reductions in yield [6-9]. For example, high-temperature stress inhibited the elongation of 
rice pollen tubes during the anthesis stage, which resulted in poor fertilization and ultimately spikelet sterility $[10,11]$. Similarly, high-temperature stress during the flowering or grain filling stages of wheat reduced the photosynthetic rate, increased the damage to the thylakoid membrane, and decreased yield by $29 \%$ and $44 \%$, respectively [9]. Furthermore, Barkley et al. [12] indicated that wheat grain yield was reduced by $21 \%$ per $1{ }^{\circ} \mathrm{C}$ increase during the reproductive stage. Therefore, understanding the response of crops to high temperatures during critical periods is essential to ensure cereal production.

Maize is among the three most important grain crops in the world and provides a stable source of food for many populations [13]. With global population growth, the demand for maize as food, feed, and fuel continues to rise and is projected to reach a new peak by 2024 [14]. Numerous studies have been conducted to explore the responses of maize to increased temperatures [15-17]. High temperatures accelerate the development of maize, shorten its growth period, and reduce photosynthetic product accumulation [18,19]. Gabaldón-Leal et al. [20] found that the critical maximum temperature at flowering ranged from $32-35^{\circ} \mathrm{C}$ for maize and, at temperatures above $35^{\circ} \mathrm{C}$, the reproductive organs develop poorly, pollination and fertilization cannot proceed normally, and grain filling and the seed-setting rate decrease, which ultimately leads to reduced production [21-24]. High-temperature stress has become a major threat to current and future maize production in some regions [19].

China is the second largest maize producer and consumer in the world [25], and the $3 \mathrm{H}$ region is one of the two major maize production areas in China. Changes in maize production in this region have an important influence on national food security. However, extreme weather events during the summer maize growing season in the Huang-Huai-Hai $(3 \mathrm{H})$ region have increased over the past decades $[26,27]$. High temperatures above $35^{\circ} \mathrm{C}$ often occur in July and August, which is the period of tasseling and pollen dispersal, and these processes are very sensitive to high temperatures. Therefore, it is particularly important to understand the impact of the occurrence of high-temperature events at this critical stage on maize yield. However, previous studies have focused predominantly on the mechanism of the effects of high temperatures on maize yield $[22,28,29]$ and the effect of climate change on maize growth and development $[13,15,30]$, while few have quantified the occurrence characteristics of high-temperature events in critical stages at a smaller timescale or assessed the impact of high-temperature events on summer maize yield when heading into the maturity period in this region.

The goals of this study are (1) to evaluate the temporal trend of high-temperature events when heading into the maturity period of summer maize by calculating the daily maximum temperatures from 1980-2016 in the 3H region and (2) to quantify the effect of high-temperature events when heading into maturity on maize yield at hourly and daily timescales.

\section{Materials and Methods}

\subsection{Study Region}

The study region is located in eastern China $\left(31^{\circ} 23^{\prime}-42^{\circ} 36^{\prime} \mathrm{N}, 110^{\circ} 21^{\prime}-122^{\circ} 42^{\prime} \mathrm{E}\right)$ and covers most of the $3 \mathrm{H}$ region of China (Figure 1). The study area comprises a total area of $6.6 \times 10^{5} \mathrm{~km}^{2}$, and the maize-growing area in the study area accounts for $35 \%$ of the national total planting area and provides $40 \%$ of the maize production nationwide. The study area is located in the mid-latitude zone of the monsoon climatic region in eastern China. In summer (June-August), the long-term mean temperature is $24.6^{\circ} \mathrm{C}$ and the precipitation is $122.9 \mathrm{~mm}$, and in winter (December-February), the average temperature is $-2.3^{\circ} \mathrm{C}$ and the precipitation is $9.8 \mathrm{~mm}$. The average annual temperature and precipitation decrease with increasing latitude from south to north. Previous research suggests that climatic factors, such as temperature, sunshine duration, and precipitation are the primary ecological factors that affect the growth and development of maize. Crop adaptability varies under different ecological conditions, and maize adapts to ecological environmental changes by adjusting its growth duration [25]. In this study, we divided the study area into two sub-regions, the southern and northern sub-regions (Figure 1). The southern region borders the subtropical zone, while the northern region borders the mid-temperate zone. There are certain differences in climatic conditions and summer 
maize growth duration between the two sub-regions (Table 1). In addition, we also provide the air temperatures and average phenological dates of the summer maize growing season in the $3 \mathrm{H}$ region over the past 37 years (Table 2).

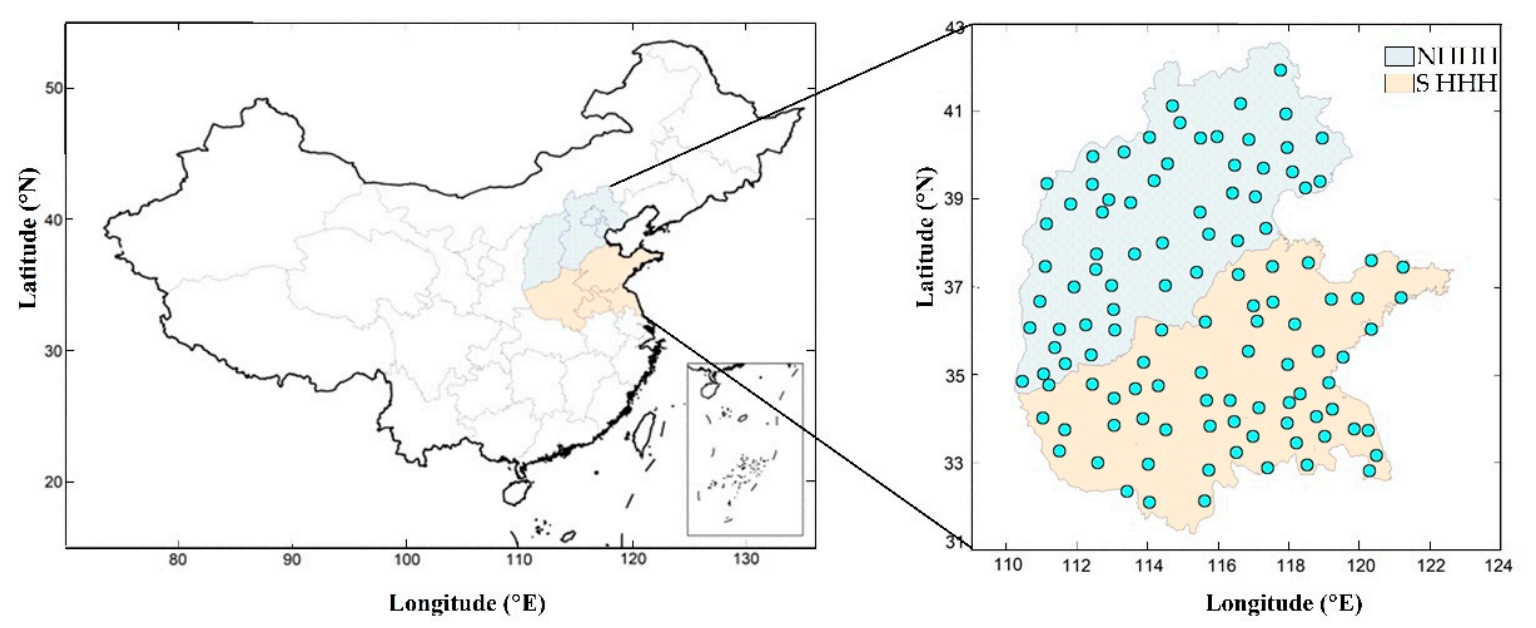

Figure 1. The location of the study area in China and the distribution of the meteorological stations. $\mathrm{S} 3 \mathrm{H}$ and $\mathrm{N} 3 \mathrm{H}$ indicate the southern Huang-Huai-Hai region and the northern Huang-Huai-Hai region, respectively.

Table 1. The annual average values of climate factors and the average phenological dates of summer maize in the Huang-Huai-Hai region from 1980 to 2016.

\begin{tabular}{cccccccccc}
\hline Region & T $\left({ }^{\circ} \mathbf{C}\right)$ & SSD $(h)$ & Prec $(\mathbf{m m})$ & Sowing & Heading & Maturity & VGP (d) & RGP (d) & WGP (d) \\
\hline S3H & 14.29 & 2129 & 771.4 & $6 / 11$ & $8 / 4$ & $9 / 18$ & 54 & 45 & 99 \\
N3H & 10.44 & 2480 & 491.6 & $6 / 16$ & $8 / 9$ & $9 / 26$ & 54 & 48 & 102 \\
\hline
\end{tabular}

Annual average temperature (T); sunshine duration (SSD); precipitation (Prec); vegetative growth period (VGP); reproductive growth period (RGP); whole growth period (WGP).

\subsection{Data Sources}

The data, which mainly include meteorology, phenology, and yield data, were obtained from three databases. A comprehensive analysis of these data was conducted to characterize the occurrence of high-temperature events when heading into the maturity period of summer maize and its relationship with yield in the study area. The first data set came from the National Meteorological Information Center of the Central China Meteorological Administration (http://data.cma.cn/) and contained daily maximum temperature $\left(T_{\max }\right)$, average temperature $\left(T_{\text {avg }}\right)$, minimum temperature $\left(T_{\min }\right)$, and precipitation data. In the study area, 112 meteorological stations with complete records were selected and the high-temperature event indices (high-temperature hours (HTH) and high-temperature degrees (HTD)) were calculated by using the daily $T_{\max }$ data observed when heading to maturity in summer maize during 1980-2016. These first databases included 60 and 52 stations in the $\mathrm{S} 3 \mathrm{H}$ and $\mathrm{N} 3 \mathrm{H}$ regions, respectively. The spatial positional data for each meteorological station were obtained from the National Geomatics Center of China (Figure 1).

The second data set consists of the phenological data (sowing, heading, and maturity dates) for summer maize from 1980-2016. In the study, we defined the vegetative growth period as that from sowing to heading and the reproductive growth period as that from heading to maturity. These data also collected from the National Meteorological Administration to evaluate the mean values of the summer maize heading and maturity dates at each station from 1980-2016, which were regularly recorded phenological dates at these stations. 
Table 2. The climatic factors and their trends during the summer maize growth season in the Huang-Huai-Hai region from 1980 to 2016.

\begin{tabular}{|c|c|c|c|c|c|c|c|c|c|c|c|}
\hline \multirow{2}{*}{ Region } & \multirow{2}{*}{ Month } & \multicolumn{2}{|c|}{$T_{\min }$} & \multicolumn{2}{|c|}{$T_{a v g}$} & \multicolumn{2}{|c|}{$T_{\max }$} & \multicolumn{2}{|c|}{ SSD } & \multicolumn{2}{|c|}{ Prec } \\
\hline & & Mean $\left({ }^{\circ} \mathrm{C}\right)$ & Trend $\left({ }^{\circ} \mathrm{C} \mathrm{a}^{-1}\right)$ & Mean $\left({ }^{\circ} \mathrm{C}\right)$ & Trend $\left({ }^{\circ} \mathrm{Ca}^{-1}\right)$ & Mean $\left({ }^{\circ} \mathrm{C}\right)$ & Trend $\left({ }^{\circ} \mathrm{Ca}^{-1}\right)$ & Mean (h) & Trend $\left(\mathrm{h} \mathrm{a}^{-1}\right)$ & Mean (mm) & Trend $\left(\mathrm{mm} \mathrm{a}^{-1}\right)$ \\
\hline \multirow{4}{*}{$\mathrm{S} 3 \mathrm{H}$} & 6 & $19.95 \pm 0.74$ & $0.0432^{* *}$ & $24.61 \pm 0.77$ & 0.0303 ** & $29.90 \pm 0.95$ & 0.0225 & $198.0 \pm 23.02$ & -0.8965 ** & $99.83 \pm 43.07$ & -0.1966 \\
\hline & 7 & $23.28 \pm 0.89$ & $0.0378^{* *}$ & $26.84 \pm 0.91$ & $0.0300 *$ & $31.15 \pm 1.04$ & 0.0255 & $182.9 \pm 28.23$ & -0.8367 & $189.4 \pm 48.51$ & 0.6470 \\
\hline & 8 & $22.45 \pm 0.86$ & $0.0383 * *$ & $25.93 \pm 0.84$ & 0.0250 & $30.27 \pm 0.95$ & 0.0160 & $190.4 \pm 33.66$ & $-1.221 *$ & $145.9 \pm 45.75$ & 0.7821 \\
\hline & 9 & $17.42 \pm 0.95$ & $0.0508^{* *}$ & $21.54 \pm 0.85$ & $0.0298^{*}$ & $26.62 \pm 1.06$ & 0.0124 & $177.7 \pm 31.58$ & $-1.184 *$ & $75.11 \pm 39.96$ & 0.5134 \\
\hline \multirow{4}{*}{$\mathrm{N} 3 \mathrm{H}$} & 6 & $16.57 \pm 0.70$ & 0.0361 ** & $22.72 \pm 0.75$ & $0.0221 *$ & $29.20 \pm 0.95$ & 0.0195 & $235.6 \pm 23.89$ & $-1.283^{* *}$ & $67.70 \pm 16.83$ & 0.0450 \\
\hline & 7 & $19.53 \pm 0.84$ & $0.0405 * *$ & $24.50 \pm 0.82$ & $0.0293 *$ & $30.15 \pm 0.99$ & 0.0275 & $217.5 \pm 24.27$ & $-1.309 * *$ & $128.9 \pm 39.96$ & 0.2204 \\
\hline & 8 & $18.16 \pm 0.71$ & $0.0342 * *$ & $22.93 \pm 0.75$ & $0.0311^{* *}$ & $28.65 \pm 1.01$ & $0.0321^{*}$ & $214.9 \pm 24.88$ & $-0.7685^{*}$ & $105.7 \pm 31.39$ & -0.7270 \\
\hline & 9 & $12.47 \pm 1.10$ & $0.0589 * *$ & $17.80 \pm 0.92$ & $0.0332 *$ & $24.29 \pm 1.10$ & 0.0159 & $202.7 \pm 27.33$ & $-1.580^{* *}$ & $61.25 \pm 21.37$ & $0.6554 *$ \\
\hline
\end{tabular}

Note: $T_{\min }, T_{a v g}, T_{\max }, \mathrm{SSD}$, and Prec indicate the minimum temperature, average temperature, maximum temperature, sunshine duration, and precipitation, respectively. ${ }^{\circ} \mathrm{C} \mathrm{a}^{-1}$ means

$1{ }^{\circ} \mathrm{C}$ per year and $\mathrm{h} \mathrm{a}^{-1}$ means $1 \mathrm{~h}$ per year. *,**: significant at $p<0.05$ and $p<0.01$, respectively. 
The third database contained the planting area, yield, and annual yield of summer maize in each province from 1980-2016, and these data were extracted from the Agricultural Information Network of China. According to the ratio of the yield to the planted area of each province, we calculated the average yield for the $\mathrm{S} 3 \mathrm{H}$ and $\mathrm{N} 3 \mathrm{H}$ regions to estimate the impact of high-temperature events from heading to maturity on grain yield.

\subsection{Data Analysis}

\subsubsection{High-Temperature Event Indices}

We treated $35^{\circ} \mathrm{C}$ as the critical threshold of high-temperature stress to evaluate the impact of this stress on summer maize yield. The HTH and HTD were used as the main indices to describe the high-temperature events and then to analyze the occurrence and impact of high-temperature events from heading to maturity. Based on the high-temperature event indices at each station over the past 37 years, the temporal trends of the high-temperature index of the $\mathrm{S} 3 \mathrm{H}, \mathrm{N} 3 \mathrm{H}$, and $3 \mathrm{H}$ regions were fitted by simple linear regression to reveal the local and $3 \mathrm{H}$-regionwide changes in recent decades. The HTH calculation method refers to Bristow and Abrecht [31], and the HTD calculation method was based on Shi et al. [32]. The calculation methods for HTH and HTD are as follows:

$$
\begin{gathered}
T_{1}=\frac{D}{\pi} \times \arcsin \frac{\left(T_{c}-T_{\text {mini }}\right)}{T_{\text {maxi }}-T_{\text {mini }}} \\
T_{2}=D-T_{1} \\
H H_{i}=T_{2}-T_{1} \\
H T H=\sum_{d_{h}}^{d_{m}} H H_{i} \\
H T D=\sum_{d_{h}}^{d_{m}} H D_{i} \\
H D_{i}=0, T_{\text {maxi }}<T_{c} \\
H D_{i}=T_{\text {maxi }}-T_{c}, T_{\text {maxi }} \geq T_{c}
\end{gathered}
$$

where $T_{1}$ and $T_{2}(\mathrm{~h})$ are intermediate variables; $D$ is day length (h); $T_{c}$ is the critical temperature $\left(35^{\circ} \mathrm{C}\right) ; T_{\operatorname{maxi}}$ and $\mathrm{T}_{\min i}$ are the maximum and minimum temperature on day $i ; \mathrm{HH}_{i}$ is high-temperature hours above the temperature threshold of $35^{\circ} \mathrm{C}$ on day $i ; d_{h}$ and $d_{m}$ are heading and maturity dates, respectively; $\mathrm{HTH}$ indicates the accumulated $H H_{i}$ from heading to maturity; $H D_{i}$ is the high temperature degrees on day $i$, and $H T D$ indicates the accumulated $H D_{i}$ from heading to maturity.

\subsubsection{The Impact of High-Temperature Events on Summer Maize Yield}

The yield of maize is affected by climatic factors, as well as non-climatic factors, such as variety improvement, fertilization, and cultivation practices. To analyze the relationship between climatic factors and yield more accurately, the influence of non-climatic factors must be eliminated [33]. Schlenker and Lobell [34] proposed that the linear and quadratic trends of the years can be considered to exclude the contribution of non-climatic factors to yield. Therefore, in this study, the nonlinear model of Lobell et al. [35] was used to perform a sensitivity analysis of the crop yield time series in detail from 1980 to 2016. A regional panel data analysis tool (Eviews6.0) was used to evaluate the effect of high-temperature events on summer maize yield. The specific model is as follows:

$$
\log (\text { Yield }(i, t))=c i+d_{1 i} \times \text { year }+d_{2 i} \times \text { year }^{2}+\beta \times X(i, t)+\varepsilon(i, t)
$$

where $i$ is the sub-region (southern $3 \mathrm{H}(\mathrm{S} 3 \mathrm{H})$ and northern $3 \mathrm{H}(\mathrm{N} 3 \mathrm{H})$ region) of the study; $t=1980 \ldots$, 2016; $c$ is a fixed effect; $d$ is the time trend coefficient; $\beta$ is the independent variable parameter; $X(i, t)$ are 
independent variable parameters, including climatic factors, such as the average temperature $\left(T_{a v g}\right)$, minimum temperature $\left(T_{\min }\right)$, maximum temperature $\left(T_{\max }\right)$, and precipitation; and $\varepsilon(i, t)$ is the error term. Statistical analyses were performed using SPSS software (SPSS 25.0, SPSS, Inc., Chicago, IL, USA). Graphics were created with Microsoft Excel 2016 (Microsoft Corporation, Redmond, WA, USA).

\section{Results}

\subsection{Variation Trends of Temperature, Precipitation, and Yield from Heading to Maturity}

The changes in $T_{\text {avg }}, T_{\max }$, and $T_{\min }$ from heading to maturity in summer maize showed an upward trend in the $3 \mathrm{H}$ region during 1980-2016 (Table 3). For the S3H and N3H regions during the study period, $T_{\text {avg }}$ exhibited a significant increase and $T_{\min }$ had an extremely significant increase, but $T_{\max }$ only exhibited a significant increase in the $\mathrm{N} 3 \mathrm{H}$ region only. Overall, the temperature increase was higher in the $\mathrm{N} 3 \mathrm{H}$ region than in the $\mathrm{S} 3 \mathrm{H}$ region, and the trend was that $T_{\min }$ increased most dramatically, followed by $T_{\text {avg }}$ and $T_{\max }$. There was no significant change in precipitation over the study period; the precipitation increased slightly, by $1.61 \mathrm{~mm}$ per 10-yr period, but fluctuated greatly interannually. According to the statistics, the average yield of summer maize in the $3 \mathrm{H}$ region was $3335 \mathrm{~kg} \mathrm{ha}^{-1}$ in the $1980 \mathrm{~s}$ and rose to $5648 \mathrm{~kg} \mathrm{ha}^{-1}$ in 2016, with an average annual increase of approximately $64.26 \mathrm{~kg} \mathrm{ha}^{-1}$. From 1980 to 2016, yields increased significantly in the 3H region, but the difference in yield between the $\mathrm{S} 3 \mathrm{H}$ and $\mathrm{N} 3 \mathrm{H}$ regions was not significant. The $\mathrm{S} 3 \mathrm{H}$ region had the highest maize grain yield at $4951 \mathrm{~kg} \mathrm{ha}^{-1}$, which was $9.55 \%$ higher than the yield of the $\mathrm{N} 3 \mathrm{H}$ region $\left(4519 \mathrm{~kg} \mathrm{ha}^{-1}\right)$, but its coefficient of variation was also higher than that of the $\mathrm{N} 3 \mathrm{H}$ region.

\subsection{Variation Trends of HTH and HTD during the Heading to Maturity Period}

The values of HTH and HTD from heading to maturity across the $3 \mathrm{H}$ region suggested an increasing trend, particularly in the S3H region, during 1980-2016 (Figure 2). The HTH values increased markedly, by $1.30 \mathrm{~h}, 0.79 \mathrm{~h}$, and $1.17 \mathrm{~h}$ per decade in the $\mathrm{S} 3 \mathrm{H}, \mathrm{N} 3 \mathrm{H}$, and $3 \mathrm{H}$ regions, respectively. During the study period, the average values of $\mathrm{HTH}$ were $3.94 \mathrm{~h}$ and $2.68 \mathrm{~h}$ for the $\mathrm{S} 3 \mathrm{H}$ and $\mathrm{N} 3 \mathrm{H}$ regions, respectively. The increases in $\mathrm{HTD}$ per 10 -yr period were $0.80^{\circ} \mathrm{C}, 0.41^{\circ} \mathrm{C}$, and $0.59^{\circ} \mathrm{C}$ for the $\mathrm{S} 3 \mathrm{H}, \mathrm{N} 3 \mathrm{H}$, and $3 \mathrm{H}$ regions, respectively. The average HTDs between heading and maturity during the period of $1980-2016$ were $2.55{ }^{\circ} \mathrm{C}$ and $1.72{ }^{\circ} \mathrm{C}$ for the $\mathrm{S} 3 \mathrm{H}$ and $\mathrm{N} 3 \mathrm{H}$ regions, respectively.
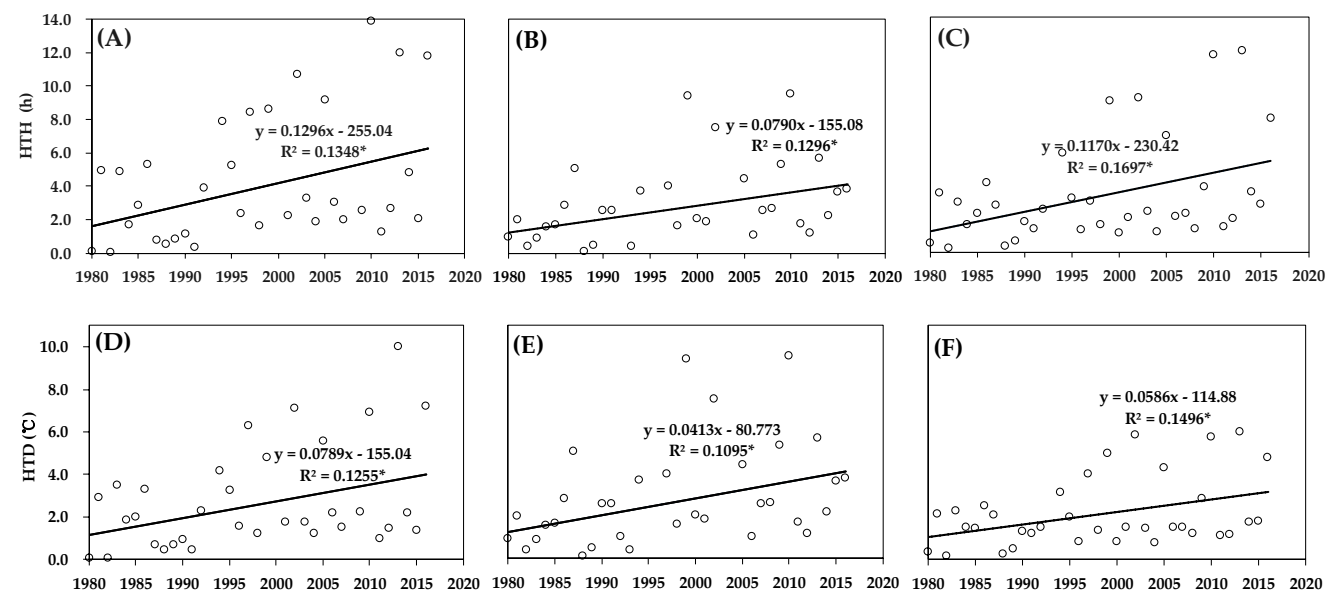

Figure 2. The trends of two high-temperature index variables ((A-C), high-temperature hours $(\mathrm{HTH})$; (D-F), high-temperature degrees (HTD)) between heading and maturity in the Huang-Huai-Hai summer maize region during 1980-2016. (A,D), (B,E), and (C,F) indicate the southern Huang-Huai-Hai region $(\mathrm{S} 3 \mathrm{H})$, northern Huang-Huai-Hai region $(\mathrm{N} 3 \mathrm{H})$, and whole Huang-Huai-Hai region $(3 \mathrm{H})$, respectively. 
Table 3. Change trends in temperature, precipitation from heading to maturity and yield changes in the Huang-Huai-Hai summer maize region during 1980-2016.

\begin{tabular}{|c|c|c|c|c|c|c|c|c|c|c|c|}
\hline \multirow{3}{*}{ Region } & \multicolumn{2}{|c|}{$T_{\min }$} & \multicolumn{2}{|c|}{$T_{a v g}$} & \multicolumn{2}{|c|}{$T_{\max }$} & \multicolumn{2}{|c|}{ Prec } & \multicolumn{3}{|c|}{ Yield } \\
\hline & Mean & Trend & Mean & Trend & Mean & Trend & Mean & Trend & Mean & Trend & $\mathrm{CV}$ \\
\hline & $\left({ }^{\circ} \mathrm{C}\right)$ & $\left({ }^{\circ} \mathrm{C} 10 a^{-1}\right)$ & $\left({ }^{\circ} \mathrm{C}\right)$ & $\left({ }^{\circ} \mathrm{C} 10 \mathrm{a}^{-1}\right)$ & $\left({ }^{\circ} \mathrm{C}\right)$ & $\left({ }^{\circ} \mathrm{C} 10 a^{-1}\right)$ & $(\mathrm{mm})$ & $\left(\mathrm{mm} \mathrm{10a^{-1 } )}\right.$ & $\left(\mathrm{kg} \mathrm{ha}^{-1}\right)$ & $\left(\mathrm{kg} \mathrm{ha}^{-1} \mathrm{a}^{-1}\right)$ & $(\%)$ \\
\hline $\mathrm{S} 3 \mathrm{H}$ & $20.37 \pm 0.70$ & $0.360 * *$ & $24.12 \pm 0.68$ & $0.236^{*}$ & $28.79 \pm 0.86$ & 0.153 & $184.4 \pm 54.66$ & 4.410 & 4951 & $62.02 * *$ & 16.77 \\
\hline $\mathrm{N} 3 \mathrm{H}$ & $16.10 \pm 0.72$ & $0.441^{* *}$ & $21.14 \pm 0.66$ & $0.319^{* *}$ & $27.20 \pm 0.83$ & $0.273^{*}$ & $161.1 \pm 35.97$ & -0.146 & 4519 & $66.37^{* *}$ & 14.92 \\
\hline $3 \mathrm{H}$ & $18.33 \pm 0.69$ & $0.400^{* *}$ & $22.70 \pm 0.64$ & $0.277^{*}$ & $28.03 \pm 0.79$ & 0.211 & $173.3 \pm 40.97$ & 1.161 & 4780 & $64.26^{* *}$ & 15.53 \\
\hline
\end{tabular}

Note: ***: significant at $p<0.05$ and $p<0.01$, respectively. 


\subsection{Impacts of HTH and HTD Changes on Summer Maize Yield from Heading to Maturity}

Panel data analysis was performed to identify the impacts of HTH and HTD variations on yield (Figure 3). The results suggested that the increases in HTH and HTD had a negative effect on maize production. In the $\mathrm{S} 3 \mathrm{H}$ region, an increase in $\mathrm{HTH}$ by $1 \mathrm{~h}$ corresponded to a decrease of $0.54-1.13 \%$ in yield, and a $1{ }^{\circ} \mathrm{C}$ increase in HTD corresponded to a $1.34-4.29 \%$ decline in yield, whereas in the N3H region, a $1 \mathrm{~h}$ increase in $\mathrm{HTH}$ corresponded to a decrease of $0.17-0.89 \%$ in yield, while a $1{ }^{\circ} \mathrm{C}$ increase in HTD corresponded to a $0.21-0.71 \%$ decline in yield. In summary, the high-temperature events have a greater impact on the summer maize yield in the $\mathrm{S} 3 \mathrm{H}$ region than in the $\mathrm{N} 3 \mathrm{H}$ region.

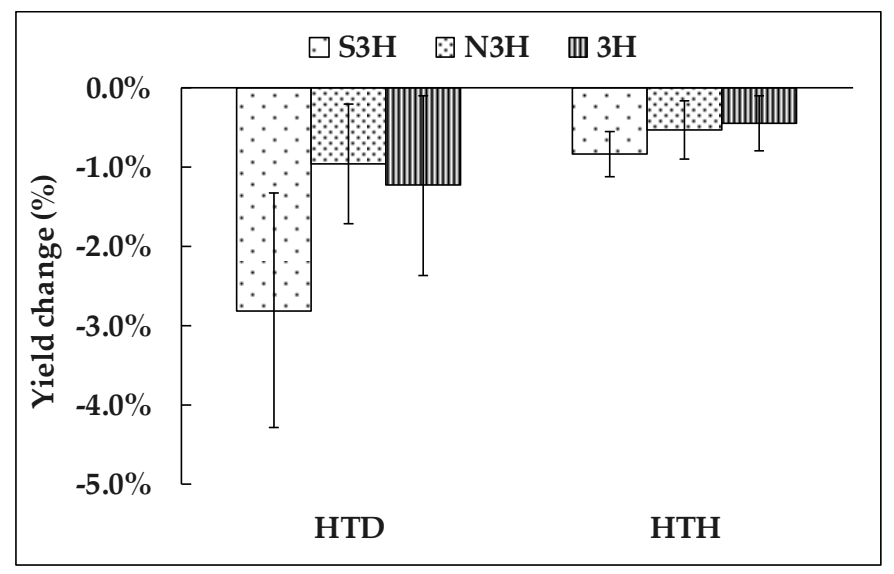

Figure 3. Summary of panel data analysis coefficients showing the estimated sensitivity to changes in high-temperature hours $(\mathrm{HTH},+1 \mathrm{~h})$ and high-temperature degrees $\left(\mathrm{HTD},+1^{\circ} \mathrm{C}\right)$ for summer maize in terms of estimated yield changes. $\mathrm{S} 3 \mathrm{H}, \mathrm{N} 3 \mathrm{H}$, and $3 \mathrm{H}$ indicate the southern Huang-Huai-Hai region, northern Huang-Huai-Hai region, and whole Huang-Huai-Hai region, respectively.

\section{Discussion}

With climatic warming, the frequency and severity of high-temperature events during the reproductive growth period of crops have increased remarkably, and high-temperature events, as a serious threat to maize production, have been a growing concern [36]. Crops have different optimum and critical temperature thresholds in different development and growth phases; when these thresholds are exceeded, a series of physiological processes associated with yield formation are affected, leading to dramatic yield losses [17]. In fact, many studies have reported on the impact of high temperatures around the flowering period on maize, but information obtained from applying indices of high-temperature events to study their influence on the development and yield of summer maize from heading to maturity in the $3 \mathrm{H}$ region is inadequate. We used quantitative methods to estimate the variation characteristics of high-temperature events in recent decades based on phenological and meteorological data from the major summer maize production areas in China. Our results indicated that the intensity of high-temperature events between heading and maturity notably increased during 1980-2016 and that there was a difference in their occurrence frequency between the $\mathrm{S} 3 \mathrm{H}$ and $\mathrm{N} 3 \mathrm{H}$ regions.

In recent decades, the air temperature across the $3 \mathrm{H}$ region during the heading to maturity period of summer maize showed a significant upward trend. $T_{\min }$ increased by $0.40^{\circ} \mathrm{C}$ per decade, that is, the night-time temperature increased rapidly and the variation trend was mostly consistent with the trend of global climate change [37,38]. Bahuguna et al. [39] found that warmer nights promote night respiration rates and increase the consumption of photosynthate, resulting in decreased biomass. Wang et al. [21] suggested that at the $30^{\circ} \mathrm{C}$ night temperature, yield losses mainly result from a decrease in kernel number rather than in kernel weight under high-temperature stress; compared with those in a control treatment, the maize yield and grain number under a warming treatment decreased greatly by $23.8 \%$ and $25.1 \%$, respectively. 
In this study, we assessed the response of summer maize yield to HTH and HTD by analyzing panel data, and a negative effect on yield caused by the increase in high-temperature events was noted across the $\mathrm{S} 3 \mathrm{H}$ and $\mathrm{N} 3 \mathrm{H}$ regions. High temperatures above $35^{\circ} \mathrm{C}$ in the $3 \mathrm{H}$ region usually occur in July and August, but, in this period, the pollination stage of summer maize also occurs. High temperatures prolong the anthesis-silking interval, decrease pollen activity, induce pollen sterility, and inhibit pollen tube growth, which induces yield reduction [19,28]. Additionally, Zhang et al. [27] reported that high temperatures and droughts generally occurred between the tasseling and kernel milk stages in the $3 \mathrm{H}$ region in recent decades and the occurrence of high temperatures increases potential evaporation and reduces the supply of soil water [40], which could be another reason for the decline in production. The background temperature of the $\mathrm{S} 3 \mathrm{H}$ region was higher than that of the $\mathrm{N} 3 \mathrm{H}$ region, and the time trend analysis revealed that the intensity of high-temperature events increased faster in the $\mathrm{S} 3 \mathrm{H}$ region, with HTD and HTH increasing by $0.80{ }^{\circ} \mathrm{C}$ and $1.30 \mathrm{~h}$ per decade, respectively. Consequently, a more severe negative effect on maize yield was recorded in the $\mathrm{S} 3 \mathrm{H}$ region than in the $\mathrm{N} 3 \mathrm{H}$ region. It should be noted that temperature variability and extreme temperature events will become more prevalent in the future due to the impact of climate change.

The sowing calendar and the crop growth rate affect whether the critical phenology phase coincides with the high-temperature period. Adjusting the sowing date is an important adaptation strategy for avoiding the risks of high temperature and drought during the critical period for maize, ensuring yield and adapting to climate change [41-43]. However, a winter wheat-summer maize rotation system was implemented across most of the $3 \mathrm{H}$ Plain. Adjusting the sowing window of summer maize will have an impact on the winter wheat growing season [44]. Yadav et al. [45] suggested that heat-tolerant maize genotypes have higher photosynthetic capacity under heat stress, can better adapt to high-temperature environments, and the yield is less affected by high temperatures. New climate resilient maize showed better adaptability and yield performance than current major commercial varieties under high temperatures, low input, and drought conditions $[46,47]$. Therefore, selecting and cultivating heat-tolerant summer maize varieties is an effective measure to reduce the damage of high temperatures to maize.

In this study, we used meteorological and yield data from the heading to maturity period of summer maize in the $3 \mathrm{H}$ region from 1980 to 2016 to evaluate the impact of high-temperature events on yield. However, crop varieties, soil properties, irrigation management, and cultivation technology are also important limiting factors that contribute to maize yield and yield stability [48,49]. Therefore, to assess the influence of climatic change on crop production more accurately in future studies, these factors should be emphasized and assessed individually.

\section{Conclusions}

From 1980-2016, both the air temperature and the intensity of high-temperature events during the maize heading to maturity period across the $3 \mathrm{H}$ region showed significant upward trends. The increases in HTH and HTD had a negative effect on the summer maize yield in the $\mathrm{S} 3 \mathrm{H}$ and $\mathrm{N} 3 \mathrm{H}$ regions, but this effect was more severe in the $\mathrm{S} 3 \mathrm{H}$ region. Given the uncertainties surrounding climate change and the increase in extreme high temperature events, and considering the close connection between the planting times of winter wheat and summer maize, improving the heat tolerance of maize through variety improvement is an effective strategy for addressing this issue.

Author Contributions: Conceptualization, S.W. and C.C.; methodology, S.W. and C.C.; software, S.W. and C.C.; formal analysis, S.W. and C.C.; writing-original draft preparation, S.W. and J.L.; writing-review and editing, J.L., T.L., X.W., and A.P. All authors have read and agreed to the published version of the manuscript.

Funding: This work was supported by the Special Fund for Agro-scientific Research in the Public Interest (201503118), the National Key Technology R\&D Program of China (2015BAC02B02), the Central Public-interest Scientific Institution Basal Research Fund of Institute of Crop Science (Y2016PT12), and the Innovation Program of CAAS (Y2016XT01).

Conflicts of Interest: The authors declare no conflict of interest. 


\section{References}

1. IPCC. Summary for Policymakers. In Global Warming of $1.5^{\circ} \mathrm{C}$. An IPCC Special Report on the Impacts of Global Warming of $1.5^{\circ} \mathrm{C}$ Above Pre-Industrial Levels and Related Global Greenhouse Gas Emission Pathways, in the Context of Strengthening the Global Response to the Threat of Climate Change, Sustainable Development, and Efforts to Eradicate Poverty; Masson-Delmotte, V.P., Zhai, H.-O., Pörtner, D., Roberts, J., Skea, P.R., Shukla, A., Pirani, W., Moufouma-Okia, C., Péan, R., Pidcock, S., et al., Eds.; World Meteorological Organization: Geneva, Switzerland, 2018; p. 7.

2. Pfleiderer, P.; Schleussner, C.; Kornhuber, K.; Coumou, D. Summer weather becomes more persistent in a 2 degrees C world. Nat. Clim. Chang. 2019, 9, 666.

3. Sun, X.; Long, Z.; Song, G.; Chen, C. High-Temperature Episodes with Spatial-Temporal Variation Impacted Middle-Season Rice Yield in China. Agron. J. 2018, 110, 961-969. [CrossRef]

4. Djanaguiraman, M.; Perumal, R.; Ciampitti, I.; Gupta, S.; Prasad, P.V.V. Quantifying pearl millet response to high temperature stress: Thresholds, sensitive stages, genetic variability and relative sensitivity of pollen and pistil. Plant Cell Environ. 2017, 41, 993-1007. [CrossRef]

5. Farooq, M.; Bramley, H.; Palta, J.A.; Siddique, K.H. Heat Stress in Wheat during Reproductive and Grain-Filling Phases. Crit. Rev. Plant Sci. 2011, 30, 491-507. [CrossRef]

6. Porter, J.R.; Semenov, M.A. Crop responses to climatic variation. Philos. Trans. R. Soc. B Biol. Sci. 2005, 360, 2021-2035. [CrossRef]

7. Singh, V.; Nguyen, C.T.; Van Oosterom, E.J.; Chapman, S.C.; Jordan, D.R.; Hammer, G.L. Sorghum genotypes differ in high temperature responses for seed set. Field Crop. Res. 2015, 171, 32-40. [CrossRef]

8. Begcy, K.; Nosenko, T.; Zhou, L.-Z.; Fragner, L.; Weckwerth, W.; Dresselhaus, T. Male Sterility in Maize after Transient Heat Stress during the Tetrad Stage of Pollen Development. Plant Physiol. 2019, 181, 683-700. [CrossRef]

9. Djanaguiraman, M.; Narayanan, S.; Erdayani, E.; Prasad, P. Effects of high temperature stress during anthesis and grain filling periods on photosynthesis, lipids and grain yield in wheat. BMC Plant Biol. 2020, 20. [CrossRef]

10. Zhang, C.; Li, G.; Chen, T.; Feng, B.; Fu, G.; Yan, J.; Islam, M.R.; Jin, Q.; Tao, L.; Fu, G. Heat stress induces spikelet sterility in rice at anthesis through inhibition of pollen tube elongation interfering with auxin homeostasis in pollinated pistils. Rice 2018, 11. [CrossRef]

11. Wu, C.; Cui, K.; Tang, S.; Li, G.; Wang, S.; Fahad, S.; Nie, L.; Huang, J.; Peng, S.; Ding, Y. Intensified pollination and fertilization ameliorate heat injury in rice (Oryza sativa L.) during the flowering stage. Field Crop. Res. 2020, 252. [CrossRef]

12. Barkley, A.P.; Tack, J.; Nalley, L.L.; Bergtold, J.; Bowden, R.; Fritz, A. Weather, Disease, and Wheat Breeding Effects on Kansas Wheat Varietal Yields, 1985 to 2011. Agron. J. 2014, 106, 227-235. [CrossRef]

13. Tanumihardjo, S.A.; McCulley, L.; Roh, R.; Lopez-Ridaura, S.; Palacios-Rojas, N.; Gunaratna, N.S. Maize agro-food systems to ensure food and nutrition security in reference to the Sustainable Development Goals. Glob. Food Secur. 2020, 25. [CrossRef]

14. ISO. Guide 35:2017 Reference Materials—Guidance for Characterization and Assessment of Homogeneity and Stability; International Organization for Standardization: Geneva, Switzerland, 2017; p. 105.

15. Cairns, J.E.; Crossa, J.; Zaidi, P.H.; Grudloyma, P.; Sanchez, C.; Araus, J.L.; Thaitad, S.; Makumbi, D.; Magorokosho, C.; Bänziger, M.; et al. Identification of Drought, Heat, and Combined Drought and Heat Tolerant Donors in Maize. Crop. Sci. 2013, 53, 1335-1346. [CrossRef]

16. Ordóñez, R.A.; Savin, R.; Cossani, C.M.; Slafer, G.A. Yield response to heat stress as affected by nitrogen availability in maize. Field Crop. Res. 2015, 183, 184-203. [CrossRef]

17. Prasad, P.V.V.; Bheemanahalli, R.; Jagadish, S.V.K. Field crops and the fear of heat stress-Opportunities, challenges and future directions. Field Crop. Res. 2017, 200, 114-121. [CrossRef]

18. Lobell, D.B.; Burke, M.B. On the use of statistical models to predict crop yield responses to climate change. Agric. For. Meteorol. 2010, 150, 1443-1452. [CrossRef]

19. Lizaso, J.I.; Ruiz-Ramos, M.; Rodríguez, L.; Gabaldon-Leal, C.; Oliveira, J.; Lorite, I.; Sánchez, D.; García, E. Impact of high temperatures in maize: Phenology and yield components. Field Crop. Res. 2018, 216, 129-140. [CrossRef] 
20. Siebers, M.H.; Slattery, R.A.; Yendrek, C.R.; Locke, A.M.; Drag, D.; Ainsworth, E.A.; Bernacchi, C.J.; Ort, D.R. Simulated heat waves during maize reproductive stages alter reproductive growth but have no lasting effect when applied during vegetative stages. Agric. Ecosyst. Environ. 2017, 240, 162-170. [CrossRef]

21. Wang, Y.; Tao, H.; Zhang, P.; Hou, X.; Sheng, D.; Tian, B.; Wang, P.; Huang, S. Reduction in seed set upon exposure to high night temperature during flowering in maize. Physiol. Plant. 2020, 169, 73-82. [CrossRef]

22. Wang, Y.; Tao, H.; Tian, B.; Sheng, D.; Xu, C.; Zhou, H.; Huang, S.; Wang, P. Flowering dynamics, pollen, and pistil contribution to grain yield in response to high temperature during maize flowering. Environ. Exp. Bot. 2019, 158, 80-88. [CrossRef]

23. De Storme, N.; Geelen, D. The impact of environmental stress on male reproductive development in plants: Biological processes and molecular mechanisms. Plant Cell Environ. 2014, 37, 1-18. [CrossRef]

24. Dupuis, I.; Dumas, C. Influence of temperature stress on invitro fertilization and heat-shock protein-synthesis in maize (zea-mays 1) reproductive tissues. Plant Physiol. 1990, 94, 665-670.

25. Li, S.; Zhao, J.; Dong, S.; Zhao, M.; Li, C.; Cui, Y.; Liu, Y.; Gao, J.; Xue, J.; Wang, L.; et al. Advances and Prospects of Maize Cultivation in China. Sci. Agric. Sin. 2017, 50, 1941-1959.

26. Wang, B.; Liu, D.L.; Asseng, S.; Macadam, I.; Yu, Q. Impact of climate change on wheat flowering time in eastern Australia. Agric. For. Meteorol. 2015, 209, 11-21.

27. Zhang, Z.; Yang, X.; Liu, Z.; Bai, F.; Sun, S.; Nie, J.; Gao, J.; Ming, B.; Xie, R.; Li, S. Spatio-temporal characteristics of agro-climatic indices and extreme weather events during the growing season for summer maize (Zea mays L.) in Huanghuaihai region, China. Int. J. Biometeorol. 2020, 64, 827-839. [CrossRef]

28. Sánchez, B.; Rasmussen, A.; Porter, J.R. Temperatures and the growth and development of maize and rice: A review. Glob. Chang. Biol. 2014, 20, 408-417. [CrossRef]

29. Alam, A.; Seetharam, K.; Zaidi, P.H.; Dinesh, A.; Vinayan, M.T.; Nath, U.K. Dissecting heat stress tolerance in tropical maize (Zea mays L.). Field Crop. Res. 2017, 204, 110-119. [CrossRef]

30. Lobell, D.B.; Bänziger, M.; Magorokosho, C.; Vivek, B. Nonlinear heat effects on African maize as evidenced by historical yield trials. Nat. Clim. Chang. 2011, 1, 42-45. [CrossRef]

31. Bristow, K.; Abrecht, D. Daily temperature extremes as an indicator of high temperature stress. Soil Res. 1991, 29, 377-385. [CrossRef]

32. Shi, P.; Tang, L.; Wang, L.; Sun, T.; Liu, L.; Cao, W.; Zhu, Y. Post-Heading Heat Stress in Rice of South China during 1981-2010. PLoS ONE 2015, 10, e0130642. [CrossRef]

33. Hu, Q.; Buyanovsky, G. Climate Effects on Corn Yield in Missouri. J. Appl. Meteorol. 2003, 42, $1626-1635$. [CrossRef]

34. Schlenker, W.; Lobell, D.B. Robust negative impacts of climate change on African agriculture. Environ. Res. Lett. 2010, 5. [CrossRef]

35. Lobell, D.B.; Schlenker, W.; Costa-Roberts, J. Climate Trends and Global Crop Production Since 1980. Science 2011, 333, 616-620.

36. Gourdji, S.M.; Sibley, A.M.; Lobell, D.B. Global crop exposure to critical high temperatures in the reproductive period: Historical trends and future projections. Environ. Res. Lett. 2013, 8. [CrossRef]

37. IPCC. Climate Change 2014: Synthesis Report. Contribution of Working Groups I, II and III to the Fifth Assessment Report of the Intergovernmental Panel on Climate Change; IPCC: Geneva, Switzerland, 2014.

38. Carter, E.K.; Melkonian, J.; Riha, S.J.; Shaw, S.B. Separating heat stress from moisture stress: Analyzing yield response to high temperature in irrigated maize. Environ. Res. Lett. 2016, 11, 094012. [CrossRef]

39. Bahuguna, R.N.; Solis, C.A.; Shi, W.; Jagadish, K.S.V. Post-flowering night respiration and altered sink activity account for high night temperature-induced grain yield and quality loss in rice (Oryza sativa L.). Physiol. Plant. 2017, 159, 59-73. [CrossRef]

40. Ju, H.; Van Der Velde, M.C.; Lin, E.; Xiong, W.; Li, Y. The impacts of climate change on agricultural production systems in China. Clim. Chang. 2013, 120, 313-324. [CrossRef]

41. Rahimi-Moghaddam, S.; Kambouzia, J.; Deihimfard, R. Adaptation strategies to lessen negative impact of climate change on grain maize under hot climatic conditions: A model-based assessment. Agric. For. Meteorol. 2018, 253, 1-14. [CrossRef]

42. Tian, B.; Zhu, J.; Nie, Y.; Xu, C.; Meng, Q.; Wang, P. Mitigating heat and chilling stress by adjusting the sowing date of maize in the North China Plain. J. Agron. Crop. Sci. 2019, 205, 77-87. [CrossRef] 
43. Huang, M.; Wang, J.; Wang, B.; Liu, D.L.; Yu, Q.; He, D.; Wang, N.; Pan, X. Optimizing sowing window and cultivar choice can boost China's maize yield under $1.5^{\circ} \mathrm{C}$ and $2{ }^{\circ} \mathrm{C}$ global warming. Environ. Res. Lett. 2020, 15. [CrossRef]

44. Zhao, J.; Yang, X. Distribution of high-yield and high-yield-stability zones for maize yield potential in the main growing regions in China. Agric. For. Meteorol. 2018, 248, 511-517. [CrossRef]

45. Yadav, S.K.; Tiwari, Y.K.; Kumar, D.P.; Shanker, A.K.; Lakshmi, N.J.; Vanaja, M.; Maheswari, M. Genotypic Variation in Physiological Traits Under High Temperature Stress in Maize. Agric. Res. 2015, 5, 119-126. [CrossRef]

46. Setimela, P.; Magorokosho, C.; Lunduka, R.; Gasura, E.; Makumbi, D.; Tarekegne, A.; Cairns, J.E.; Ndhlela, T.; Erenstein, O.; Mwangi, W. On-Farm Yield Gains with Stress-Tolerant Maize in Eastern and Southern Africa. Agron. J. 2017, 109, 406-417. [CrossRef]

47. Setimela, P.; Gasura, E.; Thierfelder, C.; Zaman-Allah, M.; Cairns, J.E.; Boddupalli, P.M. When the going gets tough: Performance of stress tolerant maize during the 2015/16 (El Nino) and 2016/17 (La Nina) season in southern Africa. Agric. Ecosyst. Environ. 2018, 268, 79-89.

48. Zhao, J.; Yang, X.; Sun, S. Constraints on maize yield and yield stability in the main cropping regions in China. Eur. J. Agron. 2018, 99, 106-115. [CrossRef]

49. Ma, D.; Li, S.; Zhai, L.; Yu, X.; Xie, R.; Gao, J. Response of maize barrenness to density and nitrogen increases in Chinese cultivars released from the 1950s to 2010s. Field Crop. Res. 2020, 250. [CrossRef]

Publisher's Note: MDPI stays neutral with regard to jurisdictional claims in published maps and institutional affiliations.

(C) 2020 by the authors. Licensee MDPI, Basel, Switzerland. This article is an open access article distributed under the terms and conditions of the Creative Commons Attribution (CC BY) license (http://creativecommons.org/licenses/by/4.0/). 